does not convince, but he will prompt new thinking. As such the publication of The Last Utopia may come to be considered a significant "breakthrough" in the historiography of human rights.

James W. St.G. Walker

University of Waterloo

\title{
Martin Klimke, The Other Alliance: Student Protest in West Germany and the United States in the Global Sixties (Princeton, NJ: Princeton University Press, 2010).
}

One hundred and fifty years ago Charles Darwin inveighed against the view that a scientist's role is one of observing, rather than theorising. One "might as well go into a gravel-pit and count the pebbles and describe the colours," argued the great naturalist. "[A]ll observation must be for or against some view if it is to be of any service." I would add that in history observation itself is never neutral: if an historian first does not situate himself in his own history, what he takes to be simple observations in reality are reflections of the dominant power relations of the society in which he lives. Reading Martin Klimke's The Other Alliance: Student Protest in West Germany and the United States in the Global Sixties painfully brings Darwin's thoughts to mind.

Klimke sets three goals for his book. First, he proposes to explore "the exact processes through which [New Left] activists" from the United States and West Germany "established contact, shared ideas, and adopted each other's social and cultural practices" (2). Klimke terms this relation between U.S. and West German activists the "other alliance," in contrast to the "official transatlantic partnership" between the United States and West Germany [7]. Second, Klimke proposes to use the US-West German relation "as a case study," in order to show "for the very first time how the U.S. government monitored and reacted to the global student protest during the 1960s" [2]. Finally, Klimke hopes that his study will "contribute to an explanation of the internationality of the sixties and this decade's role in the postwar political order" [7].

Klimke partially succeeds in meeting his first two goals. He leaves no stone unturned in going through archives on both sides of the Atlantic and uncovering the numerous connections between the American Students for a Democratic Society (SDS) and the (West) German Socialist Student League, Sozialistischer Deutscher Studentbund (SDS). He is equally diligent in exploring both U.S. and West German governmental evaluations of Germany's SDS.

Unfortunately, to understand why the two SDSes were able to share and exchange ideas involves far more than tracing the connections between the organizations. If New Leftists from the U.S. and from West Germany drew on 
the same intellectual stock, if they interpreted world events in a similar manner, and if the practical actions they took were strikingly similar, this suggests that activists in both countries shared a similar relationship to the world's socioeconomic order. Klimke never really poses this question. However, he does present large amounts of evidence, especially his account of Berlin SDS leader Rudi Dutschke's thinking (65-91, et passim), with which we can infer such a common relation to power. During the 1960s Dutschke developed an anti-imperialist analysis that placed movements for national liberation at the center of the struggle against capitalism and for socialism. He believed, for example, that Vietnam's national liberation struggle demanded more from New Leftists than just opposition to the American war; it required actively identifying with the Vietnamese and seeing their victories as victories for the New Left (68). Moreover, Dutschke saw these understandings as conferring a special responsibility upon German SDSers. According to Klimke, Dutschke sought to establish an institute which, among other tasks, would train German New Leftists as " revolutionary socialists' who could 'participate directly in the struggle and, as revolutionary experts, help set up socialism in those countries where the revolution had won"” [96]. Dutschke had even grander missionary visions. He planned to enter a college in California and from there "build up another base from which to disseminate his ideas from California into South America and counter American imperialism from within" [97].

These positions, as well as German SDS positions on America's Black Power movement, closely paralleled American SDS positions. But a reader would be hard-pressed to learn this fact from Klimke's book. Klimke fails to mention, much less analyse, the rise of Revolutionary Youth Movement (RYM) politics in the American SDS, despite the fact that these politics, which became SDS's leading politics by early 1969, tallied, almost line for line, with Klimke's account of Dutschke's politics. Neither does Klimke examine the strengths and weaknesses of such politics

More troubling still, RYM politics and German SDS's anti-imperialist politics were heavily shaped by the theory and practice of Black Power. In an extensive chapter dealing with the German SDS's relations to the American Black Power movement, Klimke does acknowledge this, but he fails to articulate at least the main outlines of black nationalist thought as developed by the two leading Black Power organizations of the time, the Student Non-Violent Coordinating Committee and the Black Panther Party. Without this background, however, readers will not know that both the American and German SDSes selectively took "militancy" from Black Power politics while ignoring the demands those politics placed on white activists.

Listen: None of this is to deny that Klimke has done some valuable work here. He understands on a cultural and socio-psychological level why German SDSers so eagerly took up the doctrine of Third World liberation, and, 
especially important, why and how they interpreted that doctrine in the ways that they did. But Klimke, rather than develop this valuable thinking and use it as the core of an important book, fritters away his energy displaying the various archival nuggets he has found. Behind this failure, and The Other Alliance's ultimate shortcoming, lies a philosophy of history which Klimke articulates in his book's penultimate paragraph:

Taking a more comprehensive, multidimensional perspective on the global sixties will help us escape the traditional front lines as well as fuel further research. Regardless of whether we judge the decade's legacies as positive or negative, a thorough investigation will keep alive its philosophical, artistic, cultural, and political richness as a significant, if at times contradictory, site of memory, and not allow the sixties to be turned into a site of partisan bickering or oblivion [244].

In short, Klimke has opted for a history which counts stones, and describes their colours. Sometimes the description of a stone and its immediate context may be sufficient for a geologist to estimate the stone's origin; and for an historian, conversant with a particular historical period, the mere presentation of historical facts may be enough to help gauge the social and political forces involved in creating an event. But Klimke wanted to understand the relationship between social movements in the U.S. and Germany, and understand the place of the sixties in the overall post-World War II history. This is quite impossible without an analysis of the real power relations of the time: who are the oppressors; who are the oppressed; what does oppression and resistance mean to the oppressed and the oppressor? Non-partisan history cannot answer these questions. Nor can it answer the questions Martin Klimke sets for himself in The Other Alliance.

$$
\begin{aligned}
& \text { David Barber } \\
& \text { University of Tennessee at Martin }
\end{aligned}
$$

\section{Lars Schoultz, That Infernal Little Cuban Republic: The United States and the Cuban Revolution (University of North Carolina Press, 2009).}

Lars Schoultz is a highly decorated American political scientist who has spent three decades writing about United States - Latin American relations. That Infernal Little Cuban Republic is his fifth monograph, the crowning achievement of a career spent teasing the ambiguities out of mountains of American political, diplomatic and intelligence files. At 745 pages, That Infernal Little Cuban Republic is one of the most ambitious and thoroughgoing histories of the Cuban-American relationship yet written. It is also the finest.

Schoultz's stated thesis is simple, powerful and well-rehearsed. Since the Spanish American War and arguably even earlier, most U.S. policy makers have 